Zusammentassung. Vorbehandlung von 3 Tagen mit Spironolacton verringert die Mortalität und die Leberdegeneration, die durch i.v. Gabe einer toxischen Dosis Cerium Chlorid verursacht wird.

\section{K. Bjondahl, M. Möttönen and L. Nieminen}

Research Cencer, Lääke-Medipolar. SF-20360 Turku 36 (Finland) and Department of Forensic Medicine, University of Turku, SF-20520 Turku 52 (Finland), 29 November 1972.

\title{
Antiandrogenic Potency of Drugs, Evaluated by Urinary Enzyme Excretion Technique
}

Among the numerous enzymatic activities in urine, only acid phosphatase is related to male genital secretions and to androgenic activity in man and laboratory animals $\mathbf{1 , 2}$ Acid phosphatase activity in urine derives partly from serum and partly from prostatic secretions ${ }^{3}$. As a consequence, urinary acid phosphatase activity in women and in female laboratory animals is significantly lower than in males.

In the following paper, a new antiandrogenic compound, 4'-nitro-3'-trifluoromethyl-isobutyranilide ${ }^{4}$ (Formula), was evaluated by studying the changes in urinary enzymatic activities in rats. In addition to acid phosphatase, alkaline phosphatase and 'leucine aminopeptidase' activities were determined.

Material and methods. 25 male rats of the strain FW 49 Biberach were used, weighing $200 \pm 20 \mathrm{~g}$ at the start of the experiments. The animals were kept in metabolic cages for collecting 24-h urine specimens. At the beginning of each collection period, $10.0 \mathrm{ml}$ of water were administered orally to produce maximal diuresis. After determination of control values (mean of 2 consecutive days), 20 animals were fed daily $0.2 \mathrm{~g} / \mathrm{kg}$ of the antiandrogenic compound, suspended in $10.0 \mathrm{ml}$ of water. On the $1 \mathrm{st}$, 8 th and 15 th day of the experiment, urines were collected. 5 controls received water only over the same period of time. On the 15 th day of the experiment, all animals were killed and serum was prepared for the determination of acid phosphatase activity.

Urinary acid phosphatase (SP), alkaline phosphatase (AP), and 'leucine aminopeptidase' (LAP) activities in rats following the administration of nitro-trifluoromethyl-isobutyranilide

\begin{tabular}{llll}
\hline & mU SP & mU AP & mU LAP \\
\hline Start & $93.6 \pm 14.7$ & $313.0 \pm 34.7$ & $96.2 \pm 13.3$ \\
1st day & $53.1 \pm 16.4$ & $254.9 \pm 54.2$ & $89.1 \pm 17.4$ \\
8th day & $37.4 \pm 10.5$ a & $403.8 \pm 82.1$ & $94.3 \pm 16.4$ \\
15th day & $36.7 \pm 12.3$ a & $286.9 \pm 44.3$ & $82.7 \pm 15.3$
\end{tabular}

a $P<0.01$ vs. control (start). All values refer to total $24-\mathrm{h}$ excretion.

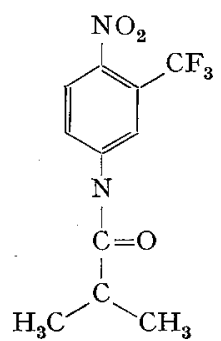

The structural formula of $4^{\prime}$-nitro- $3^{\prime}$-trifluoromethyl-isobutyranilide.
In the urines, acid phosphatase (SP; EC 3.1.3.2), alkaline phosphatase (AP; EC 3.1.3.1) and 'leucine aminopeptidase' (LAP; EC 3.4.1.2) activities were determined according to the methods published previously ${ }^{3,5}$. All enzymatic activities were calculated on the total 24-hours urine output.

Results. In the controls, no significant changes in urinary enzymatic activities were observed. In the rats under antiandrogenic medication, urinary AP- and LAPactivities were not altered significantly, whereas SPactivity revealed a statistically significant decrease. Details are compiled in the Table. SP-activity of serum amounted to $9.6 \mathrm{mU}$ in the controls and to $10.2 \mathrm{mU}$ in the animals under antiandrogenic treatment $(P>0.1)$.

Discussion. In rats, castration is accompanied by a marked drop in SP-activity in the prostate ${ }^{6}$; a similar effect is exerted by estrogens and antiandrogens ${ }^{6,7}$. The decrease in urinary SP-activity in rats under antiandrogenic medication observed in this study, may be attributed to a drug-induced drop of prostatic enzyme levels. Changes in prostatic alkaline phosphatase and aminopeptidase which were demonstrated under similar conditions ${ }^{6}$ did not take any significant influence on urinary enzymatic activities.

For screening antiandrogenic properties of new compounds, determinations of urinary SP-activity might be useful as they provide reliable results with minimal technical effort. Comparative studies might be suitable for evaluating the relative efficacy of various antiandrogens.

Zusammentassung. Bei Ratten konnte nach der Verabreichung von Nitrotrifluoromethylisobutyranilid, einer neuen antianđrogen wirksamen Substanz, ein signifikanter Abfall der sauren Phosphatase-Aktivität im Harn festgestellt werden. Andere Harnenzymaktivitäten (alkalische Phosphatase, "Leucinaminopeptidase») blieben unbeeinflusst. Die Aktivität der sauren Phosphatase im Serum zeigte nach zweiwöchiger Verabreichung des Antiandrogens keine signifikante Veränderung. Die Bestimmung der sauren Phosphatase-Aktivität im Harn eignet sich demnach zum einfachen "Screening" antiandrogener Wirkungen.

W. P. RaAB and Claudia Mörth

Vienna University Medical School, Department of

Medical Chemistry, Währingerstrasse 10,

A-1090 Wien (Austria), 27 December 1972

1 W. RAAB, Current Problems in Clinical Biochemistry (H. Huber, Bern 1968), vol. 2, p. 17.

2 W. RAAB, Clin. Chem. 18, 5 (1972).

3 W. RaAB and E. Donhoffer Klin. Wschr. 44, 1317 (1966)

1 R. Neri, K. Florance, P. Koziol and S. van Cleave, Endocrinology 97, 427 (1972).

5 W. RaAB, Helv. med. Acta 35, 290 (1970).

- M. Anderson and J. Müntzing, Invest. Urol. 9, 401 (1972)

7 R. O. Neri and M. MonAhaN, Invest. Urol. 10, 123 (1972). 